DOI https://doi.org/10.30525/978-9934-26-113-8-25

\title{
МОРФОЛОГІЧНА ПЕРЕБУДОВА ГІПОФІЗАРНО-НАДНИРКОВОЇ ВІСІ ПРИ СТРЕПТОЗОТОЦИНОВОМУ ЦУКРОВОМУ ДІАБЕТІ В УМОВАХ СТРЕСУ
}

\author{
Міськів В. А. \\ кандидат медичних наук, доцент, \\ доцент кафедри анатомії людини \\ Івано-Франківський наиіональний медичний університет \\ Жураківська О. Я. \\ доктор медичних наук, професор, \\ професор кафедри анатомії людини \\ Івано-Франківський начіональний медичний університет
}

Жураківський В. М.

кандидат медичних наук, доцент,

доиент кафедри акушерства та гінекології імені I. Д. Ланового

Івано-Франківський начіональний медичний університет

\author{
Кулинич-Міськів М. О. \\ кандидат медичних наук, дочент, \\ дочент кафедри фтизіатрії і пульмонології \\ з курсом професійних хвороб \\ Івано-Франківський начіональний медичний університет \\ м. Івано-Франківськ, Украӥна
}

У наш час цукровий діабет (ЦД) за поширеністю, невпинним ростом, ускладненнями і смертністю займає у світі лідируючі позиції серед інших захворювань [1]. Істотні медичні та соціальні аспекти проблеми ЦД обумовлені витратами на медичне обслуговування і соціальне забезпечення хворих через втрату працездатності, інвалідність та смерть [2]. У клінічних та експериментальних дослідженнях багато уваги приділено проблемі діабетичних поліендокринопатій, при цьому слід зазначити, що порушення функції гіпоталамо-гіпофізарно-надниркової системи відіграє ключову роль у патогенезі ЦД [3], натомість питання морфологічної перебудови гіпофізарно-надниркової вісі при ЦД за умов 
коморбідної патології залишилось поза увагою дослідників. Тому метою нашого дослідження було встановлення морфо-функціональної перебудови гіпофізарно-надниркової вісі на ранніх термінах розвитку стрептозотоцинового цукрового діабету за умов стресу.

Для дослідження використано 20 статевозрілих білих щурів-самців (масою тіла 180-200 г), які порівну розподілялися на 4 групи: 1 - із модельованим СЦД та хронічним іммобілізаційним стресом, 2 - із СЦД, 3 -із іммобілізаційним стресом, 4 - інтактні тварини У 1-й і 2-й групах щурів СЦД моделювали шляхом одноразового внутрішньоочеревинного введення стрептозотоцину «SIGMA» (CША), який розводили в $0,1 \mathrm{M}$ цитратному буфері $3 \mathrm{pH} \mathrm{4,5} \mathrm{(із} \mathrm{розрахунку} 6$ мг на 100 г маси тіла). У 1-й і 3-й групі тварин іммобілізіційний стрес моделювали шляхом поміщення тварини в закритий пластиковий контейнер протягом 5 годин на добу. У 1-й групі тварин моделювали СЦД і починаючи iз 14-ї доби експерименту одноразово моделювали іммобілізаційний стрес. Забір матеріалу здійснювали на 14-у добу від початку експерименту. Використали гістологічний, електронномікроскопічний, біохімічний та статистичний методи дослідження. Для морфометричних досліджень використовувались фотографії гістологічних (поле зору світлового мікроскопа Leica DM750 фотографували за допомогою цифрової фотокамери ToupCam 5.2M UHCCD C-Mount Sony) та електронограми. Морфометрію здійснювали за допомогою програми ImageJ версії 1.47t. Статистичний аналіз здійснювали за допомогою статистичного пакета Stat.Soft.Inc; Tulsa, OK, USA; Statistica 10.

На 14-у добу експерименту рівень глюкози і глікованого гемоглобіну в крові 1-ї групи щурів $\epsilon$ найвищим, порівняно з 4-ю групою і становить відповідно $15,26 \pm 2,25$ ммоль/л $\quad(p<0,001)$ та $7,42 \pm 0,72 \% \quad(p<0,01)$, у 2-й групі $-13,62 \pm 1,93$ ммоль/л $(\mathrm{p}<0,001)$ та $6,24 \pm 0,48 \%(\mathrm{p}<0,01)$, у 3-й групі - 5,16 $\pm 0,57$ ммоль/л (p>0,05) та $2,23 \pm 0,47 \%$ (p>0,05), при цьому у 4-й групі тварин вищевказані показники становлять $4,85 \pm 0,54$ ммоль/л та 2,13 $\pm 0,37 \%$. Рівень кортизолу в 1-3 дослідних групах був вірогідно більшим за такий у інтактних щурів і становив: у 1-й групі $31,13 \pm 2,74$ нг/мл, 2-й - 19,21 $\pm 2,07$ нг/мЛ, у 3-й - 29,42 22,86 нг/мл (у всіх випадках р <0,01), в інтактних тварин (4-а група) $10,17 \pm 1,21$ нг/мл. Такі біохімічні зміни у 1-й і 2-й групах щурів вказують на розвиток декомпенсованого ЦД, а в 3-й на розвиток стресу.

У тварин 1-2-ї групи кількість кортикотропних ендокриноцитів на

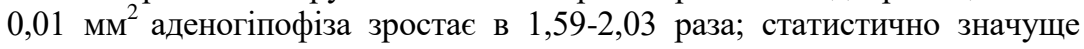
збільшується площа їхніх ядер, що призводить до зростання ядерноцитоплазматичного індексу; збільшується об'ємна щільність секреторних гранул в 2,5-1,8 раза. Зміни кортикотропних ендокриноцитів призводять 
до зростання, порівняно 3 контрольними показниками, рівня адрено-

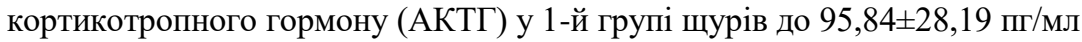

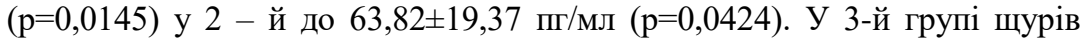
рівень АКТГ вірогідно не відрізнявся від інтактних показників і становив

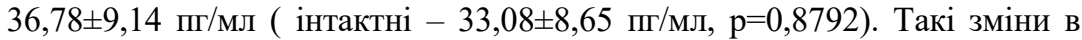
кортикотропних ендокриноцитах обумовлені декількома факторами. Так, деякі дослідники при СЦД відмітили підвищення рівня кортиколіберину в крові мишей, довівши, що нейрони пришлуночкового і дугоподібного ядер при цьому найбільше задіяні [4]. Інші автори при СЦД спостерігали підвищення функціональної активності нейронів гіпоталамуса, які виробляють кортиколіберин [5].

Гіперглікемія, підвищення активності кортикотропних ендокриноцитів, а також, стрес призводять до морфо-функціональної перебудови надниркових залоз. У корі надниркових залоз в цей термін експерименту ми виявляли достовірне потовщення пучкової зони у 1-й трупі тварин на 37\%, у 2-й - на 23,95\%, у 3-й - 29\%, порівняно з 4-ю групою (у всіх випадках $\mathrm{p}<0,05)$. У пучковій зоні відмічається достовірне зменшення площі ендокриноцитів, що пов'язано зі зменшенням у їхній цитоплазмі ліпідних крапель і підтверджується морфометричними дослідженнями на ультраструктурному рівні (об'ємна щільність ліпідних крапель зменшується у 1-3 групах на 59,7\% - 48,9 \% (у всіх випадках $\mathrm{p}<0,05$ ). Такі зміни ендокриноцитів пучкової зони вказують на значне виділення глюкокортикоїдних гормонів у кров і підтверджуються даними біохімічних досліджень.

Отже, СЦД та стрес призводять до підвищення функціональної активності гіпофізарно-надниркової вісі у відповідь на метаболічні порушення в організмі, що морфологічно проявляється: збільшенням кількості та площі кортикотропних ендокриноцитів та достовірним зростанням об’ємної щільності облямованих секреторних гранул в них; потовщення пучкової зони; зменшенням об’ємної щільності ліпідних крапель в цитоплазмі ендокриноцитів пучкової зони. Така структурна перебудова гіпофізарно-надниркової осі у щурів 1-3 груп вказує на значне виділення гормонів у кров і підтверджується зростанням рівнів АКТГ і кортизолу.

\section{Література:}

1. Ткаченко В.І., Видиборець Н.В., Коваленко О.Ф. Аналіз поширеності та захворюваності на цукровий діабет і його ускладнень серед населення України та у Київській області за 2004-2013 рр. Здобутки клінічної та експериментальної медицини. 2014. № 2. С. 177-182. 
2. Шлапак І.П., Галушко О.А. Інтенсивна терапія діабетичного кетоацидозу у хворих на ішемічний інсульт. Ocтрые и неотложные состояния в практике врача. 2015. $812 \mathrm{c.}$

3. Sharma A.N., Wigham J., Veldhuis J.D. Corticotropic axis drive of overnight cortisol secretion is suppressed in adolescents and young adults with type 1 diabetes mellitus. Pediatr Diabetes. 2014. № 15(6). C. 444-452.

4. Revsin Y., D. van Wijk, Saravia F.E. Adrenal hypersensitivity precedes chronic hypercorticism in streptozotocin-induced diabetes mice. Endocrinology. 2008; №149(7). C. 3531-3539.

5. Жураківська О.Я., Міськів В.А., Ткачук Ю.Л., Дутчак У.М., Гречин А.Б., Клипич Я.І. Морфофункціональні зміни гіпоталамо-гіпофізарно-надниркової системи при експериментальному цукровому діабеті. Conference Proceedings. Innovative technology in medicine: experience of Poland and Ukraine. (Lublin, 28-29 April 2017). Lublin, 2017. C. 117-121.

DOI https://doi.org/10.30525/978-9934-26-113-8-26

\title{
МОРФОЛОГІЧНІ ЗМІНИ ГІПОФІЗАРНО-ЯЕЧКОВОЇ ВІСІ ПРИ СТРЕПТОЗОТОЦИНОВОМУ ЦУКРОВОМУ ДІАБЕТІ
}

\author{
Себро О. Г. \\ аспірант кафедри клінічної анатомії та оперативної хірургії \\ Івано-Франківський національний медичний університет
}

Жураківська О. Я.

доктор медичних наук, професор, професор кафедри анатомії людини Івано-Франківський національний медичний університет

\section{Кулинич Г. Б.}

кандидат медичних наук, доиент, доиент кафедри гістології, ичитології та ембріології Івано-Франківський національний медичний університет м. Івано-Франківськ, Украӥна

Цукровий діабет (ЦД) $є$ однією 3 найбільш актуальних проблем клінічної медицини, що зумовлено широкою поширеністю, клінічним поліморфізмом, тяжкістю ускладнень. 3 кожним роком його частота 